\title{
Untrodden Ground: How Presidents Interpret the Constitution
}

(forthcoming, University of Chicago Press, 2014)

\author{
Harold H. Bruff \\ University of Colorado School of Law
}

January 1, 2013

This is a ticket for the Maryland Constitutionalism Schmooze of February, 2013. Like a ticket to an Orioles game, it confers a revocable license to view the contents. No commercial use or reproduction may be made. The ticketholder assumes all risks from flying objects. 
This book will examine how Presidents have interpreted the Constitution. The title comes from Washington's early remark that he stood on untrodden ground, and everything he did would become a precedent. Indeed it did, and the process continues today. Most Americans do not think of the President as the nation's most important law-interpreter, but he is. ${ }^{1}$ This role is a necessary consequence of the Constitution's creation of three separate branches, each of which interprets the Constitution constantly as it operates, independent of the views of the other two. Of course the Supreme Court oversees the interpretations of the other branches episodically, but in the case of the presidency, quite infrequently. (I count about 25 major Supreme Court precedents on presidential power in the course of over 220 years of our history; they set only loose limits on the executive's interpretive freedom.)

Within the executive branch, responsibility for interpreting the Constitution is vested in the President—by the vesting clause and by the oath to defend the Constitution that all Presidents take (sometimes twice!) as they embark on the office. Although the First Congress could have tried to place interpretive authority in an independent Attorney General, it did not do so, leaving that officer to offer interpretations that Presidents accept or decline at their pleasure. In modern parlance, the President is "the decider" on the meaning of the Constitution, although he receives constant advice from within and without the executive branch in making those decisions.

Our 44 Presidents have interpreted the Constitution in a pragmatic way that has built on the precedents set by their predecessors more than on theories offered up by their lawyers (although these theories do often encapsulate the precedents, converging arguments from history and law). I am much more interested in the view of the Constitution that is implied by what Presidents have done than in official explanations offered by the Presidents or by others in their

\footnotetext{
${ }^{1}$ On January 20, 2017, shall we make that "she”?
} 
stead to explain actions taken, except in those instances where the explanation has become an important part of the precedent. Freestanding assertions of power not tied to actual decisions do not form precedents with any punch.

Reviewing our history, I see presidential constitutional interpretation as a process very similar to generation of the common law--the accretion of precedent on the basis of past decisions in similar cases, adjusted for the facts of the case at hand and present conditions. Five factors appear to drive interpretation; they lie more in history and politics than in law as conventionally understood:

1. Personality. Each President sees the Constitution through the lens of his own character and experience. Presidents interpret the document in ways that match their temperament (Buchanan’s cowardice, Lincoln's courage, Andrew Johnson's rigidity). Although affected by the institutions that surround the President (all those lawyers), at its heart the process is highly personal.

2. Politics. A President’s political priorities affect his constitutional interpretations in fundamental ways. Some Presidents are much more interested in pressing forward on foreign policy (Kennedy, Nixon); others on domestic issues (Lyndon Johnson, Clinton). The core constitutional duty faithfully to execute the laws has received widely variant interpretation depending on whom Presidents wish to benefit, for example management versus labor during strikes. Lamentably, most Presidents have not met this duty vigorously regarding the need to benefit the most powerless groups in society, such as the Indians and the freed slaves. Some Presidents have committed grievous sins against civil liberties (Wilson, Franklin Roosevelt). Overall, most Presidents have not implemented the faithful execution duty in ways that would 
render them the tribunes of ordinary folk that they so often claim to be. This is because the governing coalitions to which they respond omit the powerless.

3. Predicaments. Of course, no President controls his own agenda more than partially. Fate intervenes, as LBJ and Clinton discovered when foreign crises disrupted their domestic plans. Urgent predicaments drive constitutional searches for solutions that work today, whatever their implications for tomorrow. Facing any crisis, Presidents naturally consider:

4. Precedents. Presidents view themselves in historical perspective, and are drawn to the examples set by their predecessors, who alone among Americans have shared the decisional pressures they face. There is comfort in precedential continuity, risk in novelty. Some precedents offer to confer legitimacy on a proposed action; others may undermine it. Truman tried (unsuccessfully) to invoke Lincoln’s Civil War precedents during the steel seizure; no modern President risks court-packing or impoundment.

5. Pushback. Congress, the public, or (sometimes) the courts react to presidential actions by accepting or rejecting them. In this way new constitutional law is made by the joint action of the three branches and the people. Acquiescence in a precedent can cement it, as has occurred with sole executive agreements. In contrast, the court-packing and impoundment episodes took options off the table, apparently permanently. In this relationship, Presidents hold the vital advantage of the initiative- they can select the action to which the nation will react.

Many of the precedents that I examine concern a President's interpretation of his own powers. Here, operative constitutional law flows from any presidential initiative that is accepted by the other branches and the public. Given the presidency’s considerable institutional advantages in taking action compared to the other branches, this opportunity to generate new law 
has immense practical advantages and a troubling capacity for abuse. To what extent is precedent binding as law? It does have force in the common law sense that yesterday's mistakes are not commonly repeated (Wilson's repression in World War I, FDR's internment in World War II). It is also far more likely that Congress and the people will accept a presidential action that has a firm base in historic precedent. Precedent thus nudges Presidents to follow familiar courses that their predecessors took successfully, instead of choosing something innovative from the menu of options that bright advisers might devise.

I also consider some presidential interpretations of the powers of Congress and of the Bill of Rights that have had important effects on how the Constitution actually operates. For example, notwithstanding John Marshall's magisterial assurances about the scope of the necessary and proper clause, Jeffersonian Presidents in the antebellum years routinely vetoed important legislation on the basis of a much narrower view of the clause, which was therefore the nation's effective interpretation for much of the period. Wilson's repression of dissent during World War I depended on a crabbed interpretation of the First Amendment, one that the nation has rejected since.

This process of presidential interpretation supports some conclusions that are relevant to current debates. First, Presidents immediately departed from originalist interpretations of the Constitution (unless they served a present purpose). Instead, Presidents have been busy making the Constitution work in their own day. Second, the operative danger that presidential action creates is ordinarily not the assertion of power that is exclusive of the other two branches, although the recent terror war had some bad moments of that sort. As in our recent history, reaction by the other branches and the people tends to squelch such claims before long. Instead, the danger lies in uncontrolled and perhaps uncontrollable presidential initiatives in crisis times 
that are not asserted to be exclusive of other branches but in which they are ill suited to participate, as in the paradigmatic example of the Cuban missile crisis.

Enough about process; what is the current state of constitutional law as generated by Presidents? Let us run down the main list of presidential powers. First, have we a unitary executive branch with the President at its head? No, nor have we ever, nor has any President seriously tried to create one. Not even Washington quite fills the bill—he had both Jefferson and Hamilton in his original cabinet, after all. True, Presidents do try to run the executive branch, but under political constraints that make formal unitariness irrelevant to them. My history focuses mostly on what I call the "constitutional cabinet," the original four officers who have important roles in executing the President's constitutional powers (to these I add attention to some modern White House aides, principally the chief of staff and the national security adviser). Presidents have picked their battles over control of the core of their own branch, with widely varying success depending on their political and managerial skills.

Presidents have conceded two critical features of unitariness to Congress. One is the existence of independent regulatory agencies, in which Presidents have long since acquiesced. The other is the early concession to the Senate of a powerful role in blocking nominations and controlling patronage. Long before the present dysfunction of the confirmation process, the Senate had deeply invaded the prospects of any President to form a unitary executive or to select judges that fit his preferences. More successfully, Presidents have maintained the critical power of civilian control over the military, but not without some very dangerous struggles, for example in the rise of those supreme egotists McClellan and MacArthur. With less fanfare, during the early part of the Cold War, Presidents struggled against constant military pressure to take 
aggressive action, and then struggled against constant military reluctance to take any action after the searing experience of Vietnam.

Whether Congress and the people acquiesce in or object to presidential actions depends on what information is available to them. Presidents have always kept secrets on their own authority. For many years, executive privilege assertions against Congress were unusual and were resolved through a political process that assumed the routine availability of information, unless it met a one of a set of evolving exceptions. Conflict has been sharper in modern times, commencing when Joe McCarthy sparked presidential assertions of broad power over executive branch information. The sins of Watergate drew attention to the constitutional executive privilege that the Supreme Court crafted, but congressional demands for information remain subject to the tides of politics.

More important is the vast expansion of classification of information after World War II, which hides much executive activity from everyone. This aspect of the national security state is a product of steadily expanding precedents concerning the President's constitutional authority to set classification policy without much input from Congress. Presidents vary in the transparency of their regimes, but not as much as their rhetoric often suggests.

The power of the President in the legislative process soon departed from the original understanding in two fundamental particulars. Under the Federalist Presidents, the constitutional power to recommend legislation lay dormant due to traditional fears of "corrupting" the sensitive legislators. Jefferson subtly demonstrated the potential for presidential management of legislation, but this power remained underdeveloped until the pre-modern presidencies of TR and 
Wilson awoke it and FDR made it an indispensable part of the presidency. LBJ, the master of Congress, demonstrated its ultimate reach and its power to help the oppressed.

The President's veto also remained undeveloped until Andrew Jackson transformed it in his war against the Bank, while declaring the independence of his interpretive power from that of the other branches. Ever since, the veto has given Presidents great power within Congress, which tries to craft bills that the President will accept. (Experience soon proved the difficulty of override, especially once the party system matured.)

Development of the President's powers within Congress fostered the maturation of the President's important power of interstitial legislation through executive orders that dwell in Justice Jackson's twilight zone, where Congress has neither clearly authorized nor forbidden executive action. Not surprisingly, it was the audacious TR who first demonstrated the capacity of this power as he added conservation to the list of values that American government was committed to pursuing. As the administrative state has grown, the executive order power has grown with it as Presidents attempt to harmonize the statutes, constantly testing for political acquiescence or disapproval.

As everyone knows, foreign policy powers immediately gravitated to the presidential office, with its powerful natural advantages in exercising them. Washington himself assumed the powers to negotiate treaties in secret, to present them to the Senate for its consent but not advice, and to interpret existing treaties. The sole executive agreement made an immediate appearance, as did the power to recognize the true government of another nation. The basic constitutional pattern that the President proposes and Congress disposes soon emerged. Congress, reduced to a frustrated and reactive stance, got even in its long period of refusing its consent to treaties, 
capped by breaking Wilson's heart. As Congress attempted to dictate foreign policy on the eve of World War II, FDR showed how a crafty President could dance at the edge of statutes while drawing public opinion his way. After the war, the bomb and the Cold War engendered the national security establishment that has permanently expanded presidential power.

The Constitution's tension between the war power of Congress and the President's designation as commander in chief began its migration toward an executive center of gravity early on, when Jefferson claimed to be deferring to Congress as he pursued the pirates. The decisive break was Polk’s deployment of the troops in harm's way in what he called southern Texas and the defenders called Mexico. As the rawboned young Lincoln understood, this put it in the power of one man to initiate war through provocation. Lincoln's own greatest emergency actions in the cauldron of Civil War, the suspension of habeas corpus and the Emancipation Proclamation, were both legally sound in my view. The question ever since has been their utility as precedents for crises less stark. The period through World War I saw constant presidential adventuring with the troops, with TR taking the palm by detaching Panama from Colombia for his canal.

The stakes rose after World War II, when the threat of Armageddon emboldened Presidents. Kennedy's unilateral conduct of the Cuban missile crisis leaves us to wonder if we must allow Presidents to serve as temporary dictators with the fate of the nation or the world in their hands, whenever time and circumstance grant no alternatives. Truman's commitment of troops to Korea without Congress stands as the modern test of the limits to initiate conventional hostilities unilaterally. Later Presidents appear to have learned some lessons from the tribulations Truman encountered as the war went along. Thus, the Presidents Bush sought congressional authorization for the Gulf wars (over the objections of the obdurate Cheney). LBJ got his initial, 
fuzzy endorsement for hostilities in Vietnam, but his record of unilateralism and duplicity in conducting the war lost the support of both Congress and the people. Richard Nixon, by doubling down on both of LBJ's sins, brought on both his own demise and the congressional risorgimento that asserted control of the imperial presidency in so many fields.

In succeeding decades, presidential power showed its resilience by recovering from the triple traumas of Vietnam, Watergate, and legislation. The junior President Bush was even allowed to forget the lesson of Vietnam by fomenting an unnecessary war through deception. In the more necessary war, the one against terror, Bush followed his instincts and his advisors into claims of exclusive executive power that were eventually rejected by both Congress and the Supreme Court. Once shorn of early excesses, claims to executive powers of detention and military trial of terror suspects appear to have stabilized legally. President Obama has followed the precedents of Bush sober on these issues. The question of interrogation- torture-has not settled into any reliable precedent, despite wide rejection of the early Bush practices and Obama's retreat from them. Obama has proved more aggressive in pursuing terrorists than many would have expected, with his expansion of targeted killings. These two Presidents have been groping for the most effective approach and calling it constitutional. Congress and the public follow gingerly along.

Reviewing all this history, no one should be surprised that an officer who is so largely allowed to define his own powers would do so in an expansive way. The scope of permissible change in the precedents has narrowed somewhat over time, as it does for accretive judicial precedent. Yet the capacity for generation of new lines of precedent is still there, as the terror war so clearly demonstrates. Compared to precedent generated by the other two, institutionally 
structured, branches, the personal generation of precedent by Presidents is more labile and far speedier.

Forty-four Presidents have trodden a lot of ground, and in places it is well-packed and solid. How will the forty-fifth President interpret her powers? Where will she step out onto untrodden ground? Will her gender inflect her interpretations, as the race of our first black President may have inflected his? I don’t know; let’s schmooze about it.

$1 / 1 / 13 / 2840$ 